\title{
Human variome project - current overview
}

\author{
Richard Cotton ${ }^{1,2}$ \\ From International Conference on Human Genetics and 39th Annual Meeting of the Indian Society of \\ Human Genetics (ISHG) \\ Ahmadabad, India. 23-25 January 2013
}

The Human Variome Project (HVP) was initiated in 2006 to foster discussion around how patient outcomes could be improved by connecting and promoting the disparate work of genetic variation database curators. In the six years that have passed since that meeting, the concept of the Human Variome Project has evolved and matured. The challenges and complexities that face the field of human genetics, form a constantly changing technology landscape. The influx of raw data that those changes bring, has necessitated a shift away from the Project's initial passive stance-a forum for the sharing of ideas and collaboration-to a more active initiative that actively engages with partners and stakeholders to establish and maintain the standards, systems and infrastructure that will enable the global collection and sharing of genetic variation information to be integrated into routine clinical practice. The Project is now well established, with over 900 HVP consortium members from 72 countries, 16 countries officially developing HVP country nodes, 6 major disease groups developing databases and over 140 databases having joined the Gene/Disease Specific Advisory Council.

With the Project Roadmap 2010-2012 nearing completion, the establishment of a new committee structure to govern the scientific aspects of the Project's activities and the incorporation of a legal entity, Human Variome Project International Limited, to act as the Project's International Coordinating Office outlined in the Roadmap are now in place. Most importantly, the Project Roadmap 2010-2012 proposed a strategy that would ultimately ensure the collection of all genetic variation information worldwide-the One Project, Two Channels, Multiple Locations Strategy. This strategy, the next Project Roadmap 2012-2016 and progress will be outlined in the presentation.

Correspondence: cotton@unimelb.edu.au

${ }^{1}$ Human Variome Project International Limited, Melbourne, Australia

Full list of author information is available at the end of the article
Authors' details

${ }^{1}$ Human Variome Project International Limited, Melbourne, Australia.

${ }^{2}$ Department of Pathology, The University of Melbourne, Australia.

Published: 21 January 2014

doi:10.1186/1755-8166-7-S1-I1

Cite this article as: Cotton: Human variome project - current overview.

Molecular Cytogenetics 2014 7(Suppl 1):11.
Submit your next manuscript to BioMed Central and take full advantage of:

- Convenient online submission

- Thorough peer review

- No space constraints or color figure charges

- Immediate publication on acceptance

- Inclusion in PubMed, CAS, Scopus and Google Scholar

- Research which is freely available for redistribution
() Biomed Central
C Biomed Central

(c) 2014 Cotton; licensee BioMed Central Ltd. This is an Open Access article distributed under the terms of the Creative Commons Attribution License (http://creativecommons.org/licenses/by/2.0), which permits unrestricted use, distribution, and reproduction in any medium, provided the original work is properly cited. The Creative Commons Public Domain Dedication waiver (http:// creativecommons.org/publicdomain/zero/1.0/) applies to the data made available in this article, unless otherwise stated. 